\title{
Research on Talent Cultivation of Innovation and Entrepreneurship of Cross-border E-commerce of Integration of Politics, Industry and Education
}

\author{
Yuanren $\mathrm{Wu}^{\mathrm{a}}$, Shuyan $\mathrm{Li}^{\mathrm{b}, \text { * }}$ \\ TSL School of Business \& Information Technology, Quanzhou Normal University, Quanzhou 362000, \\ China \\ a yuanrenwu@126.com, ${ }^{\text {b, * }}$ shuyanlee@126.com \\ *corresponding author
}

Keywords: Talent cultivation, Cross-border E-commerce, Integration of politics, Industry and education.

\begin{abstract}
The subject characteristics of cross-border e-commerce determine the importance of the combination of cross-border e-commerce teaching and practice. However, there are many problems in the traditional undergraduate training mode of cross-border e-commerce. Especially, talent training is out of line with industry practice and social needs. The solution is to establish a crossborder e-commerce talent training model which is to improve the practical ability and to lead the integration of politics, enterprise and school. Achieve professional curriculum content and professional standards docking. The process of university teaching and the process of cross-border e-commerce operation, forming quality evaluation series of personnel training of cooperative education of political, production and teaching, comprehensively improve the quality of education and teaching.
\end{abstract}

\section{Introduction}

Cross-border e-commerce is subverting the traditional mode of import and export, becoming the new growth point of China's foreign trade in the future. The Chinese government has opened a number of cross-border e-commerce pilot zones in 12 cities such as Shanghai, providing new support for the development of foreign trade in a new mode. The implementation and development of the Belt and Road Strategy and "Internet +" program creates more possibilities for cross-border electricity supplier. In 2016, the overall transaction scale of China's import and export cross-border e-commerce (including retail and B2B) reached 6.3 trillion, an increase of $23.5 \%$. In 2017, the overall size of China's import and export cross-border electricity business is expected to reach 7.5 trillion. By 2018, the overall size of China's import and export cross-border electricity business is expected to reach 8.8 trillion. Cross-border e-commerce is becoming more and more important in the national economic activities, and the demand for cross-border e-commerce talents is vigorous. However, according to China e-commerce research center on the "China cross-border electricity supplier Talent Research Report" shows, at present, there are serious gaps in cross-border electricity supplier talent, but the employment rate of talent is not high. On the one hand, in the annual graduation season college students are constantly in the market to transport "talent". on the other hand, cross-border electricity supplier enterprises can not recruit suitable talents. Some enterprises have recruited people, but these "talent" simply can not meet the needs of enterprises. Cross-border e-commerce talents should have many professional qualities and practical skills. The application oriented universities should make clear the training target, reform the training mode and innovate the training methods. In the measures, we should reconstruct the curriculum system and enhance the professional skills, strengthen the cooperation between the government and enterprises, and expand the actual combat platform ${ }^{[1]}$. 
The integration of politics, enterprises and schools means that the government set up the stage, and schools and enterprises sing. The government aims at reforming vocational education, promoting employment and promoting regional economic and social development, so as to realize sustainable industrial development and vocational education policy. Under the guidance and support of the government, both schools and enterprises are committed to improving the Social Responsibility of Enterprises and the Quality of Personnel Training in Colleges and Universities. By using the service platform between universities and enterprises, we will strengthen cooperation between enterprises and institutions of higher learning, train high-quality skilled personnel, and serve the local economic and social development ${ }^{[2]}$.

\section{Practice Research of Talent Cultivation of Innovation and Entrepreneurship of Cross- Border E-Commerce of Integration of Politics, Industry and Education}

In 2017, funded by the Jinjiang Municipal Finance Bureau, led by the Jinjiang Municipal Bureau of Commerce, innovation and entrepreneurship experimental classes formally established, in which Quanzhou Normal University and Jinjiang Cross-border Electricity Supplier Hongshan Park jointly participated. More than twenty senior students at Quanzhou Normal University became the first batch of trainees. In Hongshan Park they carry out pre-job training, talent matching, job training and graduation assessment and other content of learning and training. The class is the focus of Jinjiang electricity supplier talent projects, which is designed through " $3+1$ " model. That is, students study in school for three years and train in the Hongshan Park for one semester. The objective of cooperation is to promote cooperation among government, enterprises and school, to build a docking platform among the Park, the University and the enterprise, to explore the application of personnel training, transport flat channels, and talent training, application research and technology development normalization mechanism, and to speed up the transformation of textbook knowledge into practical productive forces and improvement the quality of personnel training. The following are analyzed from two aspects of the practical procedures and the problems that should be paid attention to.

\subsection{Practice Procedures}

The whole process of the class includes preliminary preparation, form class, pre-job training, talent matching, post practice training, graduation appraisal etc.

\subsubsection{Preliminary Preparation}

In order to unify and coordinate normal teaching and post practice training, the class of crossborder business anchored in the Academic Affairs Office of the Quanzhou Normal University. The Institute of Innovation and Entrepreneurship is fully responsible for the implementation. A vice dean who is familiar with the operation of cooperative education communicate with the Jinjiang municipal government and the enterprises in Park to pave the way for students' practical teaching. In order to establish effective communication and coordination system among government, enterprise and school, the student's thesis tutors take as their training instructors. Early through consultation with the Jinjiang Municipal Bureau of Commerce, the problem s about students' accommodation, living allowance and so on are solved by the Bureau of Commerce. Students stay in the dormitory area of the Park, and the cost of accommodation is charged by the Jinjiang municipal government, and the monthly living allowance for each student is 500 yuan. Through the distribution of business needs to the park enterprises to gather the information needed to post information, and then according to this job information to launch student registration, and then screened.

\subsubsection{Form Class}

Hold a seminar on the university, Jinjiang business bureau, training institutions, business representatives, and then by the training institutions for some pre-training training for students, such as team building, team incentive program, class regulations, precautions. 


\subsubsection{Pre-Job Training}

Students are given a four-day intensive instruction. Train students' platform skill to help students to be familiar with real operation skills and to improve the understanding of the platform, industry and related rules. It also provides opportunities for companies and students to understand each other.

\subsubsection{Talent Matching}

For one day, students enter enterprises for two-way matching between students and enterprises to help students to get into a suitable position and to help enterprises select suitable talents.

\subsubsection{Post Practice Training}

Students enter the matching business internship for about three months. During the internship, the Park will regular the students to consolidation and reinforcement business skills, including the three-days centralized advanced training in the first month and last occasional point to point business skills training. During the training period, students will be provided with internship pay and living allowance.

\subsubsection{Graduation Appraisals}

After about 4 months of practice training, according to the wishes of students and business owners, enterprises sign formal labor contracts with those willing to stay in enterprise, and students become official employees of enterprises. Students can also start their own business or other enterprises to obtain employment, and the government of Jinjiang will provide corresponding support for students who start their own business.

Through recent exchanges with students, enterprisers and training institutions, the class gained greater recognition among students and enterprises. Students believe that this model allows them to really learn about cross-border e-commerce industry development, enterprise operations management process, as well as the actual operation process, and they really get the exercise. The enterprises have greater flexibility in selecting and employing people, reducing recruitment costs and training costs. Of course, in the training process exposed some problems should further improve and reform.

\subsection{Problems Should Be Paid Attention to}

Schools should pay attention to the mobilization and screening of students before training. Because the training companies are cross-border e-commerce enterprises, Colleges and universities can solicit students according to the requirements of enterprises, information about the relevant enterprises and so on. To launch the student enrollment and screen out students who really want to work in the cross-border e-commerce industry, achieve a high degree of matching between students' will and enterprise needs.

The time of students' training should be moderate. Students training period should not be too long and too short. If too long, it is easy to make students lack sense of belonging and worry that they cannot stay in the original enterprises continue to work. In addition, business owners worry that students will not remain in business until after the end of the internship. Because of the identity of interns, it is difficult for enterprises to give them the treatment of regular employees, resulting in low treatment for students. If training period is too short, it is difficult for students to truly grasp the relevant knowledge of the industry, and so on, and it is not conducive to the development of students. Therefore, through the communication with students and business owners, students' internship period is determined to be 3-4 months. In the training period, according to the students and the wishes of the business owners, they can sign a formal employment contract as soon as possible, so that students feel at ease learning, so that business owners rest assured of training.

Senior students are practicing with the vision of future employment. But there will be some gaps between their willingness and the actual acceptance of the work, there may be a variety of psychological problems. Led teachers should follow the whole process, once students appear psychological problems, timely counseling solution. 


\section{Practical Experience and Reform Measures}

\subsection{In the Aspect of Universities}

In the process of implementing the application-oriented transformation, we reform the existing curriculum system, construct teaching materials with local characteristics, and compile the curriculum design of innovation and entrepreneurship education in cross-border e-commerce in Application-oriented universities, to enable students to fully understand the comprehensive quality of innovation and entrepreneurship must have consciousness, thinking and skills, to develop the basic occupation quality of cross-border e-commerce practitioners required, have engaged in ecommerce activities and awareness of innovation and entrepreneurship skills, occupation, and to analyze the common phenomenon of cross-border e-commerce and e-commerce application in basic practice $^{[3]}$.

We track the whole training. The dedicated teacher and graduation thesis instructors regularly take turns to Hongshan Park follow the guide, real-time grasp the dynamics of student growth, so that students can achieve an orderly docking in the school of theoretical study and business training, and deepen the mutual understanding between colleges and universities.

We explore the implementation of personnel training mode of "recycled". That is, after students entering the enterprise training, universities and enterprises track the development of students. If the students do not adapt, we can in time to further improve the training of training institutions. Further, if the students really do not meet, they can withdraw from the mechanism and return to college to continue learning.

\subsection{In the Aspect of Enterprises}

Mobilize the enthusiasm of enterprises to participate in personnel training, and strive to solve some problems arising from training students. Improve the cooperation between schools and enterprises, and realize the seamless connection between schools and enterprises on the premise of mutual benefit and win-win situation. Schools can strengthen the communication between universities and enterprises, and implement the "please come in" and "go out" measures. That is, hire industry experts and core technical backbone of enterprises to serve as professional teaching consultants, and invite senior managers and project leaders to hold professional knowledge seminars on campus ${ }^{[4]}$.

\subsection{In the Aspect of Government}

The government should strengthen the support for the deep cooperation between universities and enterprises, to promote local governments to introduce policies and regulations on school and enterprise cooperation, to overall coordination and school enterprise cooperation education and to plan practical talents training and so on.

\section{Conclusion}

There are many problems in the traditional undergraduate training mode of cross-border ecommerce. Especially, talent training is out of line with industry practice and social needs. The solution is to establish a cross-border e-commerce talent training model which is to improve the practical ability and to lead the integration of politics, enterprise and school.

\section{Acknowledgments}

This work was financially supported by the fund of Fujian Provincial Department of Education of Young Teachers in Teaching of the Scientific Research Items (Item number: JAS161048). 


\section{References}

[1]. Han Chaosheng, Problems and countermeasures in the training of innovative talents for cross border E-commerce, Chinese and foreign entrepreneurs, 2016.

[2]. Yuan Jiyu, Yu Jing, Research on enterprise e-commerce talents training mode of school enterprise cooperation, Northern economy and trade,2016, pp.143-144.

[3]. Su Hang, Construction of practice teaching system for cross border electricity providers in Universities Based on innovation and entrepreneurship capability, Foreign trade,2016, pp.139-141.

[4]. Lv Hongjing, Research on the construction of cross border electricity supplier training base based on innovation and entrepreneurship orientation, Electronic Commerce,2017, pp.87-88. 